Андрей В. Григорьев

Москва

greg988@yandex.ru

\title{
ПУШКИНСКИЙ «ОТРОК БИБЛИИ» И ЕВАНГЕЯЬСКИЙ «БЛУДНЫЙ СЫН»
}

Тех, кто впервые обращается к творческому наследию М. Ф. Мурьянова, поражает широта научных интересов и исключительная эрудиция автора. По скромным подсчетам, его перу принадлежат более двухсот исследований по романо-германскому, византийскому и славянскому средневековью, герменевтике русской литературы (с древнейших времен по начало XXв.), этимологии, исторической дексикологии русского языка, фольклористике, археографии, иконографии. ${ }^{1}$

Для меня М. Ф. Мурьянов был человеком, сформировавшим в годы студенчества мой интерес к палеославистике, византинистике и библеистике, поэтому, посвящая его памяти свою статью, мы будем реализовывать в ней задачу, которую он ставил, анализируя стихотворение А. С. Пушкина «Мирская власть»: «<...> проверить пушкинское словоупотребление на всю глубину славянской традиции, включая греческие первоисточники».

$* * *$

Обратим наше внимание на строки известного стихотворения А. С. Пушкина «Воспоминания в Царском Селе» 1829 г., которые, по мнению исследователей, содержат явную отсылку к притче о блудном сыне. ${ }^{2}$ (Дук. XV, 11-32). Как отмечает М. И. Чернышева,

(1) А. $А$. Гришунин, Несколько слов о М. Ф. Мурьянове и его статье, Philologica III 5/7 (1996) 47-50.

(2) Д. Д. БААГой, Творческий путь Пуикина (1826-1830) (Москва: Советский писатель, 1967) 461: «Даже снова посетив как-то „священный сумрак“ прекрасных дицейских садов, поэт вступает в них „с поникшею главой“ - всё с тем же жгучим раскаяньем за расточенные „в пылу восторгов скоротечных, в беспдодном вихре суеты“ сокровища сердца („Воспоминания в Царском Селе...", 1829). Свое душевное состояние он уподобляет переживаниям блудного сына, вернувшегося в отчий дом»; С. Л. ФРАнК, Религиозность Пушкина, в: Пуикин в русской философской критике: Конеи, XIX - первая половина XX в. (Москва: Книга, 1990) 393: «В личной жизни 
у Пушкина «во множестве стихов присутствуют напоминания библейских или евангельских сюжетов. Иногда для этого достаточно одного-двух слов». ${ }^{3}$ В данном случае исследователь считает, что слова, вызывающие в памяти читателя евангельскую притчу о блудном сыне, - это «отрок Библии»:4

...Сады прекрасные, под сумрак ваш священный

Вхожу с поникшею главой.

Так отрок Библии ${ }^{5}$ [безумный] расточитель,

До капли истощив раскаянья фиал,

Увидев наконец родимую обитель,

Главой поник и зарыдал...6

Также М. И. Чернышева отмечает, что в пушкинских черновиках, где отсутствует сочетание «отрок Библии», «ситуация более неопределенная, чем в беловом варианте, поскольку допускаются догадки»; по ее мнению, в черновых вариантах на евангельский сюжет намекает только слово древле:

Как древле юный расточитель,

Томясь развратной нищетой...

ИЛИ

Как древле юный расточитель,

Томим расканьем живым...

Однако, на наш взгляд, совершенно очевидно, что только сочетания «отрок Библии» для отсылки читателя к определенному

Пушкина воплощением „алтаря пенатов“ были два места - Михайловское и Царское Село. (Ср. „Вновь я посетил...“ и „Воспоминания в Царском Селе“"). В последнем стихотворении античный мотив пенатов обогащается евангельским мотивом „блудного сына“: поэт, возвратившись после скитаний - внешних и внутренних - к родному месту, в котором впервые зародилась его духовная жизнь, ощущает себя блудным сыном, возвращающимся в отчий дом».

(3) М. И. Чернышева, Уходящие слова, ускользающие смыслы (Москва: МГУП, 2009) 166.

(4) См. Словарь языка Пуикина, т. 3 (Москва: Азбуковник, 2001) 250: «Отрок Библии - о блудном сыне из библейской притчи».

(5) Выделено мной. - А. Г.

(6) А. С. Пушкин, Воспоминания в Царском Селе, в: Он жЕ, Полное собрание сочинений: в 16 тт., т. 3/1 (Москва, Ленинград: Издательство АН СССР, 1948) 189. 
месту Священного Писания не вполне достаточно. Слово «отрок» в Ветхом и Новом Заветах используется применительно ко многим персонажам, вышедшим из младенческого возраста и не достигшим юношеского: это отрок Исаак и отрок Иосиф, отрок Самуил, ${ }^{7}$ отрок Авессалом, отрок Даниил. Даже Христос именуется отроком (Ис 42:1, Мф 22:18, Лк 2:43). В то же время отметим, что сам блудный сын в Евангелии от Ауки отроком ни разу не назван.

На наш взгляд, более определенной отсылкой к евангельскому тексту у Пушкина является слово расточитель (безумный расточитель или в черновых вариантах: юный расточитель); корень данного слова встречается в следующей строфе:

В пылу восторгов скоротечных,

В бесплодном вихре суеты,

О, много расточил сокровищ я сердечных

За недоступные мечты...

Совершенно ясно, что сочетание юный расточитель или безумный расточитель было в пушкинское время не менее понятным читателю, чем известное нам сейчас блуднъй сън.

Выражение блудный сын в Евангелии отсутствует. Впервые в раннехристианской традиции как отсылка к библейскому фрагменту оно появляется в первой половине III века в сочинениях греческих (Ориген) и латинских (Тертуллиан) Отцов Церкви в фор-

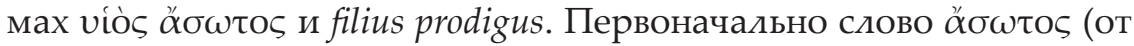

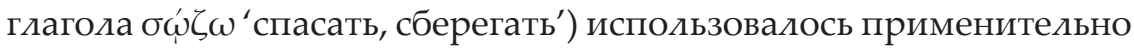
к тому, кого (что) нельзя спасти: 'безнадежный, погибший; пропащий’; в библейских текстах данное слово и однокоренное $\dot{\alpha} \sigma \omega \tau \varepsilon \dot{c} \alpha$ указывают на мотовство, необузданность, несдержанность, распущенность, нарушения общепринятого порядка жизни (Прит 7:11, 28:7, Еф. 5:18; Тит. 1:6; 1 Петр 4:4). ${ }^{8}$ Отсюда становится понятным,

(7) По мнению А. А. Николаева, именно он может иметься в виду под «отроком» в стихотворении Ф. И. Тютчева «Через дивонские я проезжал поля...»: Так отрок, чар ночных свидетель быв случайный, / Про них и днем молчание хранит»; см.: Ф. И. Тютчев, Полное собрание стихотворений, вступ. ст. Н. Я. БЕРКОвского; сост., подгот. текста и примеч. А. А. НиколАевА (Ленинград: Советский писатель, 1987).

(8) Cм.: Theological Dictionary of the New Testament, vol. I (Grand Rapids, MI, 2003) 87. 


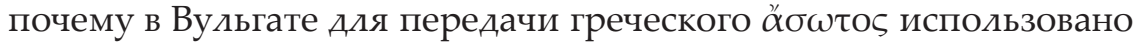
латинское prodigus ' расточительный, неумеренный; распущенный, разнузданный, безнравственный, необузданный'9 от prodigo 'гнать вперёд' > 'проводить' > 'растрачивать'. ${ }^{10}$ В дальнейшем в патрис-

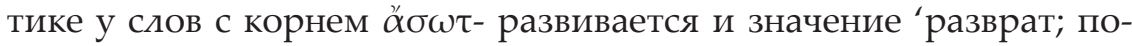
хоть' ${ }^{11}$ что сближает их со словами с корнем тофv-, выражающим всякую половую распущенность.

Непосредственно притча о блудном сыне имела раздичные истолкования в раннехристианской традиции. Под старшим и младшим сыновьями понимадись, соответственно, иудеи и язычники в их отношении к христианству, безгрешная природа ангелов и порочная человеческая природа, фарисеи и мытари, праведники и грешники. ${ }^{12}$ Тем не менее, в западном христианстве акцент обычно делался на расточительности и мотовстве блудного сына (некоторые современные зарубежные исследователи продолжают считать, что младший сын вовсе не раскаялся, так как вернулся к отцу под давлением обстоятельств, претерпев многочисленные дишения $\left.{ }^{13}\right)$. С другой стороны, в восточнохристианской, а затем и в славянской традиции образ блудного сына преимущественно связывался с идеей покаяния грешника и милосердия Божия. Закономерен и выбор слов, которые используются для номина-

(9) Oxford Latin Dictionary, fasc. 1-8 (Oxford: Oxford Universtity Press, 1968-1982) (цит. по: http://www.perseus.tufts.edu/hopper/resolveform?redir

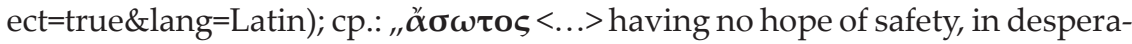
te case $<\ldots>$ abandoned" (H. G. LidDeLl, R. ScotT, A Greek-English Lexicon, rev. and augm. throughout by Sr. H. S. Jones, with a revised supplement [Oxford: Clarendon Press, 1996] 267); „, $\alpha \sigma \omega \omega \tau \omega \varsigma<\ldots>$ heillos $\zeta \tilde{\eta} v$ von schwelgerischer, verschwenderischer Lebenshaltung" (W. BAuER, Griechisch-deutsches Wörterbuch zu den Schriften des Neuen Testaments und der frühchristlichen Literatur, 6., völlig neu bearbeitete Auflage, hrsg. von K. Aland, B. Aland [Berlin-New York: Walter de Gruyter, 1988] 239).

(10) A. Walde, J. B. Hofmann, Lateinisches etymologisches Wörterbuch (Heidelberg: Winter, $\left.{ }^{4} 1964\right) 368$.

(11) G. W. H. Lampe, A Patristic Greek Lexicon (Oxford: The Clarendon Press, 1982) 255.

(12) Толковая Библия (Москва, 1998); Святое Евангелие с толкованием блаженного Феофилакта, Архиепископа Болгарского (Москва, 2000); ср.: D. A. Holgate, Prodigality, Liberrality and Meanness. The Prodigal Son In GrecoRoman Perspective (London: Sheffield Academic Press, 1999).

(13) K. B. BAiley, The Cross \& The Prodigal. Luke 15 Through the Eyes of Middle Eastern Peasants (Downers Grove, IL: IntenVarsity Press, 2005). 
ции младшего сына в раздичных языках: во многих европейских языках это производные от prodigus: франц. les fils prodique, англ. prodigal son, итал. figliol prodigo, исп. hijo pródigo и др. 'буквально: сынрасточитель'. В русском языке герой евангельской притчи - это блудный сын: ср. Блждмыи (родственное влждити 'блуждать, заблуждаться, ошибаться'; влждъ первоначально 'ошибка, заблуждение, грех', ср. латыш. blandonis бродяга, лит. blandas 'помрачение взора, ума', д.-в.-н. blentan 'ослеплять', гот. blinds 'слепой', словен. bledem 'нести чушь, бред' ). ${ }^{14}$ Таким образом, исконно на славянской почве блудный - это заблудиий, заблудивиийся, затем, вероятно, - ослепленный грехом, грешный. Ср. перифраз исследуемой истории у Аввакума: Азz, яко юнњйши Блудмый сымz, зАБлудихъ отъ Аому отца моєго, пасяхся со свиниями, єжє есть Б'сы, питАюся грБХАми, услджАдя плоть. ${ }^{15}$ При этом в сочетании блудный сын выражена и идея того, что, блуждая, человек может, покаявшись, вернуться снова на путь истинный $^{16}$ - так и происходит в исследуемой притче, поэтому такого человека нельзя назвать потерянным, как в немецком языке (нем. der verlorene Sohn - буквально 'сын, потерянный для отца').

Важно отметить, что если мы будем рассматривать употребление слова блудный в древнерусском языке, то оно обычно реализовывало исконную семантику 'имеющий отношение к заблуждению, ошибке, исповеданию ложного учения' (СлРЯ XI-XIV вв. ${ }^{17} \mathrm{I}$, 237-238) или представляло значения, которые были обусловлены греческими соответствиями: 'развратный, распутный, относящий-

(14) М. ФАсмеР, Этилологический словарь русского языка, т. 1 (Москва: Азбука, ${ }^{31996)} 177$.

(15) Аввакум, Книга бесед, в: Памятники истории старообрядчества XVII в. I/1: 1669-1675 гг. (Русская историческая библиотека, 39) (Денинград, 1927) 241.

(16) См.: об этом у А. М. Камчатнова: «На почве греческого языка при переводе Ветхого Завета, а затем и в Новом Завете [для выражения

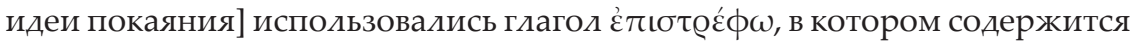
мысль о возвращении к Богу, обуславдивающем перемену практического поведения, и существительное $\mu \varepsilon \tau \alpha \dot{v} v o\llcorner\alpha$, 'перемена ума', то есть „имеется в виду внутренний переворот“» (А. М. КАмчАтнов, Покаяние, или Рассказ о кайке, которая есть, и о воротьке, которой нет, в: Одиссей-2003 [Москва: Наука, 2003]).

(17) Здесь и далее: Словарь древнерусского языка XI-XIV вв., т. 1-8(Москва: Русский язык, Азбуковник, 1988-2008-); Словарь русского языка XI-XVII вв., вып. 1-29- (Москва: Наука, 1975-2011-). 
ся к прелюбодеянию (САРЯ XI-XIV вв. I, 237-238), 'склонный к извращениям, непристойный, предосудитедьный' (САРЯ XI-XVII вв. I, 245-246). В то же время в составе выражения блудный сын данное слово связывалось исключительно с идеей покаяния и прощения:

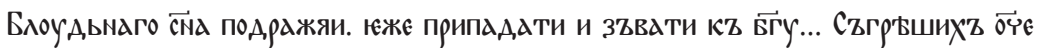

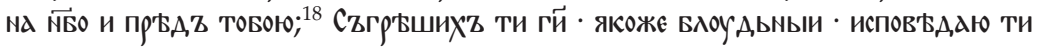

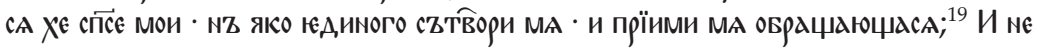

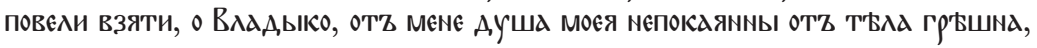

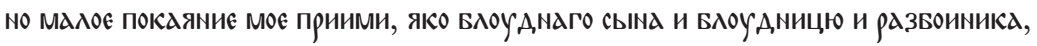
и вZскреси мя и оживи. ${ }^{20}$

Обратим внимание, что и в случае одиночного употребления, и в составе устойчивого сочетания у слова блудный отсутствовал смысл 'расточительный, мотовской', хотя о расточительстве блудного сына и говорится в византийско-церковнославянских литур-

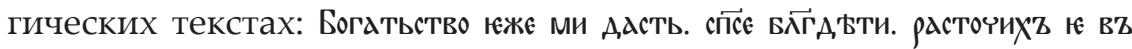
влоудьств'. ${ }^{21}$ Тодько с конца XVIII в. под вдиянием европейских языков семантика слова блудный начинает изменяться: во-первых, у него исчезает значение 'имеющий отношение к заблуждению, ошибке, исповеданию ложного учения' (последнее употребление фиксируется в Словаре русского языка XVIII в., примечательно, однако, что источником илдюстративного примера является переведённый текст: «2. Заблуждающийся, впадающий в ошибку. ПП 24. $\diamond$ Б. дух (ср. гол. dwaalgeest - еретик, нечистый дух). Блудныи дух, или кто сльдует какому блуждению. РГА 10²2), во-вторых, появляется значение 'расточительный, мотовской': «Блудный. Расточительный, моть. Евангельская притча о блудномь сынт. Блудно.

(18) М. С. МушинСкая, Е. А. МишиНА, В. С. ГОлЫшеНко (изд.), Изборник 1076 года, т. I (Москва: Рукописные памятники Древней Руси, 22009$).$

(19) M. A. Momina, N. Trunte (Hrsg.), Triodion und Pentekostarion nach slavischen handschriften des 11.-14. Jahrhunderts, Teil II: 1. bis 4. Fastenwoche (Paderborn-München-Wien-Zürich: Verlag Ferdinand Schöningh, 2010) (Abhandlungen der Nordrheinwestfälischen Akademie der Wissenschaften, Bd. 15; Patristica Slavica, Bd. 20) 260.

(20) С. П. Розанов (изд.), Жития преподобного Авраалия Смоленского и службы ему (Санкт-Петербург: Издание Отделения русского языка и словесност Императорской Академии наук, 1912) 22 (цитируется рукопись XVI в., содержащая текст XIII в.).

(21) Momina, Trunte, Triodion..., 261.

(22) Словарь русского языка XVIII века, вып. 1 (Денинград: Наука, 1985) (цит. по: http://feb-web.ru/feb/sl18/slov-abc). 
Расточительно, мотовски». ${ }^{23}$ В данном случае данный словарь следует Словарю Академии Франиузской 1762 г. (4 изд.), где соответствующее слову блудный prodiguе относится к тому, кто расточает свое имущество чрезмерныли и безумныли (бешеными) (folle 'помешанный, сумасшедший, безумный; безрассудный, шальной; глупый; бешеный, чрезмерный') тратами (расходами), слово употребляется в том числе и образно. ${ }^{24}$ В-третьих, по данным двуязычных словарей того периода ${ }^{25}$ русским словом блудный в конце XVIII первой половине XIX вв. может переводиться не только такое французское слово, как prodigue, но и lascif, débauché, déréglé. Согласно словарям Ф. И. Рейфа и И. Татищева, lascif определяется как 'похотливый, сладострастный, студный, возбуждающий похоть' (обратим внимание, что слово блудъ в Словаре Академии Российской однозначно опредедяется как 'грех против седьмой заповеди закона Божия'26); déréglé как 'распутный, бесчинно развратный'; débauché как 'шалун, забулдыга, гуляка, развращенный, забубенная голова' ${ }^{27}$ Слово débauché входит в толкование выражения блудный сын, содержащееся в Сдоварях Академии Французской 1762 и 1798 гг., которыми мог подьзоваться и А. С. Пушкин в период написания исследуемого стихотворения: «Enfant prodigue, jeune homme de famille débauché, qui retourne dans la maison paternelle» ${ }^{28}$ ['развратный (распутный) семейный молодой человек, который возвращается в отчий дом']. Образ блудного сына как развращенного, развратного, бесстыдного шалуна-гуляки активно культиви-

(23) Словарь Академии Российской, т. I (Санкт-Петербург, 1789) (далее - CAP 1789) 230 (sub verbo); ср. иное толкование того же контекста, со ссылкой на CAP, в Словаре русского языка XVIII века: «3. Б. с ы н . Ущедший из родительского дома и вернувшийся после скитаний, растратив в порочной жизни полученное от отияа имущество. Евангельская притча о блудном сынъ. САР ${ }^{1}$ I 230» (вып. 1, http://feb-web.ru/feb/sl18/slov-abc).

(24) Dictionnaire de l'Académie française ${ }^{4}$ (Paris, 1762) (sub verbo); то же в пятом издании 1798 г.

(25) Ф. И. Рейф, Новый карманный словарь русского, франиузского, немеикого и английского языков, в пользу российского юношества, по словарям Академии Российской, Академии францизской, ч. 1 (Санкт-Петербург, 1843-1845); И. ТАТИщЕв, Полный франиузско-русский словарь, т. 1 (Москва, 1828).

(26) CAP 1789, I, 230.

(27) Рейт, Новый карманный словарь..., ч. 1, 36; ч. 2, 193, 214, 408. ТАТищЕв, Полный французско-российский словарь, т. I, 205, 224; т. II, 7.

(28) Dictionnaire... ${ }^{4}$; то же в пятом издании 1798 г. 
ровался в нравоучительных европейских изданиях и произведениях изобразительного искусства того времени, от классических до популярных. Вспомним хотя бы описанные А. С. Пушкиным в своей повести «Станционный смотритель» «картинки», украшавшие «смиренную, но опрятную обитель» Самсона Вырина. «Они изображали историю блудного сына. В первой почтенный старик в колпаке и шлафроке отпускает беспокойного юношу, который поспешно принимает его благословение и мешок с деньгами. В другой яркими чертами изображено развратное поведение молодого человека: он сидит за столом, окруженный ложнылии друзьями и бесстьдньми женщинами...». ${ }^{29}$ По всей вероятности, все эти изображения восходят к сюжетам известных картин западноевропейских художников XVI-XVII вв.

Представляется, что в своем стихотворении «Воспоминания в Царском Селе» А. С. Пушкин, как и во всем своем творчестве, соединяет разнородные традиции: книжно-славянскую и западноевропейскую.

В первых редакциях упоминание раскаянья лирического героя реализует на идейном уровне связь стихотворения и литургического контекста Недели о блудном сыне. Отсюда и выбор в черновых вариантах слов древле, юный, нищета. Сравни в церковнославянском тексте канона Недели о блудном сыне (песнь четвертая, второй тропарь, ирмос:

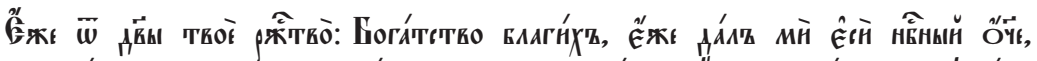

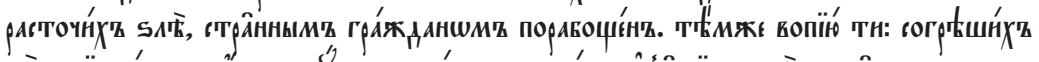

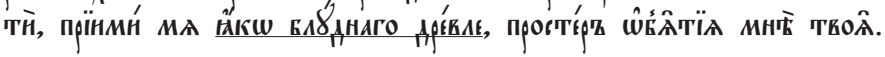

Однако в то же время в итоговом варианте «Воспоминаний...» мы читаем:

Так отрок Библии, безумный расточитель, До капли истощив раскаянья фиал...

А. С. Пушкин не использует известное выражение блудный сын (впрочем, в тексте стихотворения есть значимый глагол блуждал) и заменяет его семантической калькой с французского prodigue, при этом добавляет слово безумный, выбор которого определяется общехристианскими представлениями о грехе как помрачении ума или же калькирует французское folle 'помешанный, сума-

(29) А. С. Пушкин, Станционный смотритель, в: Он же, Полное собрание сочинений в 16 m., т. 8, 95-106. 
сшедший, безумный; безрассудный, шальной; глупый; бешеный, чрезмерный', которое, как указывалось выше, используется в Словаре Академии Французкой в дефиниции прилагательного prodigue. Церковнославянизм отрок, как уже говорилось, по нашим данным, в церковнославянских текстах, как библейских, так и богослужебных, не используется применительно к блудному сыну, зато, возможно, калькирует јеипе homme.

Влияние церковнославянского текста безусловно чувствуется и в следующих строках исследуемого стихотворения:

Увидев наконец родимую обитель,

Главой поник и зарыдал.

В пылу восторгов скоротечных,

В бесплодном вихре суеты,

О, много расточил сокровищ я сердечных

За недоступные мечты,

И долго я блуждал, и часто, утомленный,

Раскаяньем горя, предчувствуя беды,

Я думал о тебе, предел благословенный,

Воображал сии сады.

В евангельской притче блудный сын встал и пошел к отиу своему. И когда он был ещзе далеко, увидел его отецз его и сжалился; и, побежав, пал ему на шею и целювал его (Дк 15:20). Слезы блудного сына возникают в тексте Пушкина или как общехристианское выражение покаяния (см., например, библейский эпизод предательства Петра [Мф 26:75]: И вспомнил Петр слово, сказанное ему Иисусом: прежде нежели пропоет петух, трижды отречешься от Меня. И выйдя вон, плакал горько), или же под влиянием церковнославянского богослужебного текста Недели о блудном сыне:

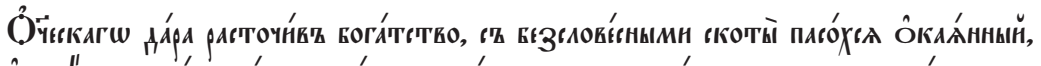

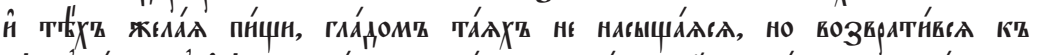

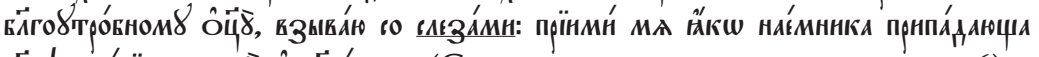

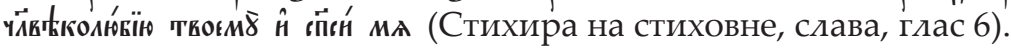

Образ расточенных сердечных сокровищ в исследуемом стихотворении может определяться западным влиянием представлений о сыне-расточителе, однако и в церковнославянском богослужебном тексте Недели о блудном сыне, как уже говорияось выше, в контексте покаяния и упования на милосердие Божие неоднократно указывается на то, что блудный сын расточил богатства (> сокровища), дарования. Как результат возникает образ обнищзавщего сердия: 


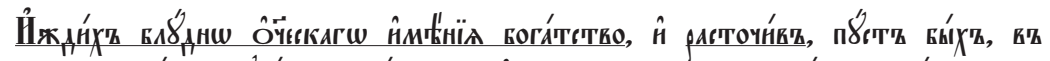

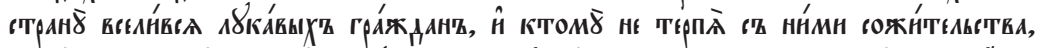

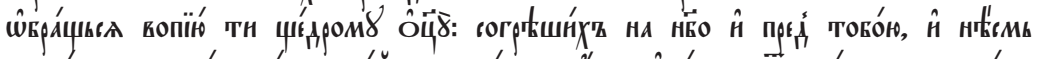

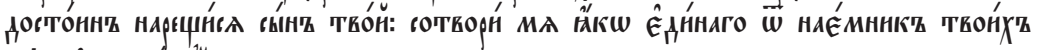

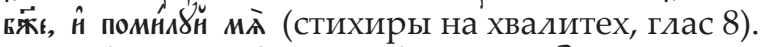

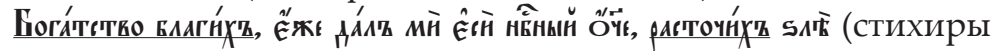
на хвалитех, глас 6).

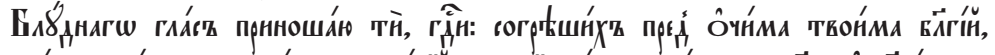

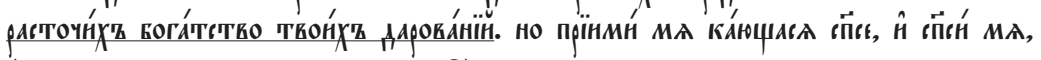
(стихиры на хвалитех, глас 2).

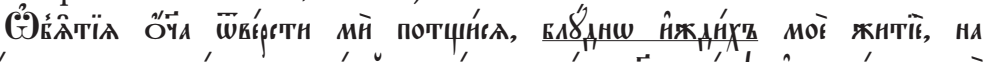

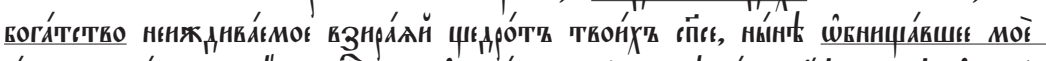

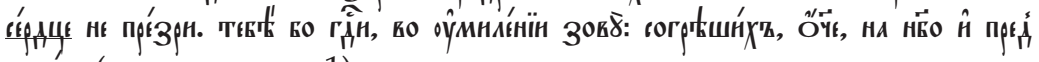
токою (седален, глас 1).

Образ иирического героя стихотворения «Воспоминания в Царском Селе» (1829 г.) противопоставлен созданному примерно в то же время образу Альбера из драмы «Скупой рыцарь» (18261830 гг.). Альбер предстает перед нами как сын-расточитель, не желающий раскаиваться (обратим внимание на строки: Он разобъет священные сосуды, // Он грязь елеем царским напоит...), поэтому Пушкин, используя применительно к нему уже знакомые нам слова безумеи, молодой расточитель, расточить, с одной стороны, добавляет для усиления характеристики «друзей» Альбера слова развратник и разгульный, а с другой - устраняет фрагменты о слезах, нищете (обнищании) и покаянии:

Я царствую! - Какой волшебный блеск!

Послушна мне, сильна моя держава;

В ней счастие, в ней честь моя и слава!

Я царствую - но кто вослед за мной

Приимет власть над нею? Мой наследник!

Безумец, расточитель молодой,

Развратников разгульных собеседник! ${ }^{30}$

Едва умру, он, он! сойдет сюда

Под эти мирные, немые своды

С толпой даскателей, придворных жадных.

Украв кдючи у трупа моего,

Он сундуки со смехом отопрет.

И потекут сокровища мои

В атласные, диравые карманы.

(30) Здесь и далее выделено мной. - А. Г. 
Он разобьет священные сосуды,

Он грязь елеем царским напоит -

Он расточит... А по какому праву? ${ }^{31}$

Таким образом, в стихотворении «Воспоминания в Царском Селе» (1829 г.) и в драме «Скупой рыцарь» (1826-1830 гг.) А. С. Пушкин для описания переживаний героев исподьзует симводы евангельской притчи о блудном сыне, которые, однако, восходят не тодько непосредственно к Библии, но и к церковнославянскому богослужебному тексту - к гимнографии Постной Триоди (Неделя о блудном сыне), с одной стороны, и к западноевропейской традиции, отраженной в том числе и в словарях Академии Французской и Академии Российской, - с другой. При этом языковые и культурные церковнославянизмы и галдицизмы сочетаются в проанализированных текстах абсодютно свободно. Герменевтический анализ позволяет найти и уточнить в текстах А. С. Пушкина алдюзии и парафразы на библейские темы, которые не получили достаточного объяснения в трудах исследователей.

\section{SUMMARY}

The article deals with the meaning of the phrase отрок Библии "the lad of the Bible" in Aleksandr Sergeevich Pushkin's poem Воспоминание в Царском Селе "Remembrances in Tsarskoye Selo." The phrase is proved to go back to the Biblical image of блудный сын "prodigal son." However, the meaining of the expression блудный сын "prodigal son" in Pushkin's text is defined by the liturgical and theological context of the hymnography of the Great Lent as well as the West European cultural tradition and especially the French standard language as attested by the Dictionary of the French Academy which influenced the Dictionary of the Russian Academy, too.

(31) А. С. Пушкин, Скупой рыцарь, в: Он жЕ, Полное собрание сочинений в 16 m., т. 7, 112-113. 